\title{
The Pre-trial Phase in a Criminal Proceeding: Ideas for an Effective Process within a Reasonable Time
}

Yrfet Shkreli

PhD Candidate at Institution of European Studies, Tirana - Albania, Judge at the First Instance Court, Përmet - Albania Email:yrfetshkreli@gmail.com

\section{Doi:10.5901/mjss.2016.v7n6p105}

\section{Abstract}

Article 6.1 of European Convention of Human Rights (the Convention) and article 42.2 of Albanian Constitution (the Constitution) guarantee to everyone who is subject to criminal proceedings the right to a final decision within a reasonable time. According to the so called "principle of determination", which governs the criminal procedure, the power of initiative rests with the parties who must take all appropriate steps to accelerate the process, but this principle does not however dispense the courts from ensuring an expeditious trial as required by Article 6. Judges and the parties in the process are under a duty to show diligence. The Convention imposes responsibility on the State to organise its legal system in such a way to enable the courts to examine the case within a reasonable time. The Albanian Code of Criminal Procedure (CCP) foresees alternative procedure for the adjudication of the disputes, and one of them is the abbreviated trial. It simplifies and shortens the time of trial, increases the effectiveness and the defendant benefits a reduction of the 1/3 of the sentence and a non application of life imprisonment. Under no circumstances, these benefits must not be to the detriment of providing justice and the court, which is not set in motion ex officio, but upon the defentant's request, accepts it only when is convinced that the issue can be resolved on the basis of the documentary evidence collected till that moment. When the court proceed with abbreviated trial, one of the longest stages of judicial proceeding, which is judicial review, is replaced by "discussion about the issue". In this content this paperwork will analyze the meaning of "the state in which the acts are", the issue of changing legal qualification of the criminal offense and if the parties can have claims regarding the invalidity of acts or the non-utility of evidence.

Keywords: Abbreviated Trial, Invalidity of Acts, Legal Qualification, Non-utility of evidence, Pre-trial Judge, Reasonable time, The Right to a Fair Trail

\section{Introduction}

According to the Albanian Code of Criminal Procedure (CCP), the preliminary investigation phase is charasterised by secrecy and, the defendant, the defense counsel or the injured party are aware of the investigative acts at the end of this phase, when the prosecutor takes the decision to send the case to trial. The request to set case for trial is a procedural act, which summarize the prosecutor's submissions regarding the criminal fact and describes the sources of evidence and the facts to which they refer. To the request is attached the trial file (Code of Criminal Procedure, Article 332.1), and the acts included in it are unrepeatable in natyre, can not be carried out in a second time during the trial, such as inspection, searches, requisition, recognition, investigative experiments, interceptions etc. In it are also included documentary evidence, transcripts of the evidence obtained during preliminary investigation, acts of expertise and documents related to the personality of the defendant. These acts and others of the preliminary investigation phase are included in the prosecutor file (Code of Criminal Procedure, Article 332.2).

The creation of two files at the end of the preliminary investigation phase, differ from each other, is known as the "rule of two files" and materializes a clear separation of the preliminary investigation phase and the trial phase. The legislator has foressen the creation of two files in order to guarantee the impartiality of the court, which must decide based only on the evidence that will be subject to judicial review (Lattanzi, 1994)

As long as, the prosecutor remains the dominus of the preliminary investigation phase and the defence role is restricted to the right to file memos, to him belongs the right to form the file for trial. For this reason I think that the formation of the trial file must follow the Italian model and the file should be formed by an independent and impartial judge, in a hearing where the parties are present (Codice di Procedura Penale, Article 431.1). 


\subsection{Research method}

In this paper I have used interpretive methods focus on analytically disclosing the meaning the why, how, or by what means judicial institutions do what they do, while showing how those practices arrange so that it can be used to generate observable outcomes and results. These methods allowed me to recognize the connection to the phenomena under study but, because the interpretative group focuses more on subjective knowledge, I have very carefully interpretated many variables in order to achieve the stated objectives of the paper. Although this limitation is generally known, I have tried to avoid this problem by not only mixing interpretative method with analytical ones but also keeping a critical eye on conclusion reached by other researchers.

\section{The Pre-trial Phase of a Criminal Proceeding According to the Albanian CCP and How to Have an Effective Process within a Reasonble Time}

Article 42/2 of the Constitution and Article 6.1 of ECHR require that cases be heard "within a reasonable time", in so providing, these acts underline the importance of rendering justice without delays which might jeopardise its effectiveness and credibility (H. v. France, 1989). These established constitutional and conventional standards guarantee the protection of all parties in the process from delays that can cause stress, insecurity and human rights violations. In criminal proceedings the reasonable period shall be calculated from the moment that the defandant is notfied for the charges against him till the day the judgement became final (Scopellitti v. Italy, 1993). The State has the obligation to organise his legal system in such a way to enable the courts to examine the case within a reasonable time, in order to create public confidence in the judicial authorities, to increase efficiency in the protection of individual rights and consolidating the rule of law, as their ultimate goal (Vocaturo v. Italy, 1991). The legal system should be organised in such a way to ensure compliance with the requirements of Article 6.1, including that of trial within a "reasonable time" (Zimmerman and Steiner v. Switzerland, 1983).

The court, as a guardian of the process, should play an active role in ensuring the reasonableness of the length of the proceedings and delivering an effective justice, since it is the only one with the power and compelling character, that has all legal, logistical and procedural remedies to fullfil this constitutional mision. The court active role is fully justified, since the parties too must show "due diligence" during proceedings and meet the obligation deriving by the law. However, we should not misunderstand and overestimate the importance of this principle and, in any case the quality of a due process of law should not be sacrificed in the name of a reasonable time and judicial economy.

The reasonableness of the length of proceedings must be assessed in the light of the particular circumstances of the case and having regard to the criteria laid down in the ECHR case-law. This jurisprudence identifies these elements (Bluchholz v. Germany, 1991):

i.) The complexity of the case: This criteria takes into evaluation the particular circumstances of the case as the complexity of the facts and legal issues, the number of accused persons (Angelucci v. Italy, 1991), the number of witnesses (Andreucci v. Italy, 1992), the intervention of other persons in the process (Eckle v. Germany, 1983).

ii.) The behaviour of the applicant and his lawyer: Although the person charged with a criminal offense is not obliged to actively cooperate with prosecuting authorities in order to speed up proceedings that may lead to his conviction, the parties too must show due dilligence during the procedings (Eckle v. Germany, 1983).

iii.) The conduct of judicial authorities: In this case will be considered only delays attributable to the State, to its judicial or administrative authorities as the: illegal suspension of the judicial process (Kutic v. Croatia, 2002), delays in establishing the judicial body, the transfer of the cases from one court to another, the bureaucracy of court secretary in taking of evidence (Guincho v. Portugal, 1984).

The request to set case for trial marks the end of the preliminary investigation phase and the beginning of trial. But before declaring the opening of judicial review the judge carries out some preparatory actions such as: setting the date of the hearing (Code of Criminal Procedure, Article 333), the judgement for getting the evidence (Code of Criminal Procedure, Article 336.1), examining requests for a speedy trial (Code of Criminal Procedure, Article 334), making effort for reconciliation (Code of Criminal Procedure, Article 338), notifying the defendant and his counsel, in order to guarantee their partecipation and verifying the appearance of the parties. During the preliminary phase the court considers the requests related to jurisdiction, its competence, merging or separating the proceedings, legitimizing the plaintiff and the civil defendant (Code of Criminal Procedure, Article 354).

Even if the aim of these provisions is to prepare the court and the parties to trial, often they are insufficent to guarantee an effective process within a reasonable time. The court, at this stage, should have a more active role, and to 
achieve such a result I think that would be necessary the introduction from the legislator of a new procedural subject, the pre-trial judge. The pre-trial judge, as an procedural subject, is foreseen not only in the Italian Code of Criminal Procedure, which has served as a model for the Albanian CCP, but also in the German one.

\subsection{The role of the pre-trial judge during the preliminary phase of the trial}

The pre-trial judge who is neither the one during the preliminary investigation phase nor the one of the judicial debate, in addition to the above actions he can perform judicial control of the legality and merits of the request to set the case for trial. The trial may take place in chambers, without the participation of the public, but by guaranteeing a fair and equal judicial debate between the parties before an idependent and impartial judge. The prosecutor and the defendat's counsel must be present at the hearing (Picardi, 2014). At the end of the trial, during which all the procedural phases according to the Albanian CCP must be respected, the pre-trial judge's decision may be final or intermediate.

In case of a final decision the judge may decide to send the case to trial or to dismiss it, and such a decision can be taken only on the basis of the data derived from acts or documents that already exist in the file. The pre-trial judge takes the decision to send the case to trial, if no criteria established for the decision of dismissal is met and in the event that the data presented by the prosecutor and the evidence are appropriate to support the indictment during judicial debate. So the pre-trial judge makes a preliminary evaluation of the possibility of "success" of the prosecution during judicial debate (Codice di Procedura Penale, Article 424). In each case, the decision must contain a clear and correct description of facts and relevant legal provisions and a summary of evidence and data resulting from them without analysing their probative force against the charges.

A dismissal decision can be taken only after a hearing date has been set and not based on acts, de plano, immediately after the prosecutor has filed for trial. Such a decision can be taken for one of the cases prescribed by law (Cass, sez. Un., 2005) . The pre-trial judge may decide to dismiss the case for reasons of law or fact (Codice di Procedura Penale, Article 425). The decission to dismiss the case can be taken:

a. If the data collected are insufficient (Corte Constituzionale, 2001)(Corte Constituzionale 2002), contradictory or inadequate to support the charges in trial (Cass, sez. IV, 2007),

b. If the indictmet is general or unclear (Cass, sez. Un, 2007). In this case the judge has the obligation to ask the prosecutor to define clearly the charges and in case of noncompliance, the judge is entitled to return the acts to the prosecutor, by indicating the cause of such a decision (Tonini, 2010). This decision marks the return to the preliminary investigation phase and for this reason is considered as extrema ratio.

The decision is intermediate when:

a. Based on the status of the documentary evidence is impossible to take a final decision, and in this case he assigns to the prosecutor the duty to conduct further investigations (Codice di Procedura Penale, Article 421). In his decision the judge determines the time limit within which the prosecutor should complete the investigations and the purpose of obtaining the evidence, but can not specify which investigative actions are necessary to be conducted (Siracusano, 1996). Such a decision can be taken also in case when the judge considers that investigations are incomplete, for evidence in favor of the defendant.

b. The judge decides to take evidence mainly, unless they are deem necessary to make a decision to dismiss the case (Codice di Procedura Penale, Article 422). At this phase of the proceedings the parties are not entitled to demand the taking of a specific evidence (Tonini, 2010).

During the pre-trial phase of the proceeding, the pre-trial judge, among other things, may change the indictmetnt presented by the prosecutor upon his request and within the limits set by law. The prosecutor can change the description of the fact, without changing the main facts, can add aggravating circumstances or can accuse the defendant for another criminal offense which has been committed with the same actions (Codice di Procedura Penale, Article 423.1). In any case the changes must be comunicated to the defendant, who has the right of defense (Tonini, 2010).

\subsection{The importance of the pre-trial judge}

The inclusion of a pre-trial judge avoids the realization of unnecessary trials and the decision to set the case to trial can be issue only if the indictment is clear and not based on conflicting and insufficient evidence. The pre-trial judge serves as a filter, which guarantees an effective trial within a reasonable time. It would protect the defendant from a long and unnecessary process, which even if in the end the defendant is declared not guilty being subject of a public trial would damage his reputation and could bring restrictions to his freedom (if judged with precautionary measures).

This encourages the parties to be more responsible in fulfillment of their duties, allows the defense to present its 
claims concerning the validity of acts conducted by the prosecutor and the not usability of the results obtained from them, that have an impact on the completeness of the investigative actions. At the end of the process, the defense can create a clearer idea how the trial may end and may choose to proceed with the abbreviated trial. On the other hand, the prosecutor should conduct any investigative action it deems necessary, otherwise risks the refusal of the request for trial.

The Albanian CCP provisions aim to avoid uneccessary proceedings and to realize an effective trial within a reasonable time. As for example: a.) The prosecutor's right to decide not to start criminal proceedings, b.) The prosecutor's right to decide at any phase of the proceedings to dismiss the case, c.) the possibility of direct and abbreviated trial. In addition, the inclusion of the pre-trial judge as a new procedural subject in the preliminary phase of a criminal proceedings guarantees the defendant right for a fair trail.

\section{The Abbreviated Trial and Its Ratio}

In the case of the abbreviated trial, which is regulated by Articles 403-406 of the Albanian CCP, the court is not set in motion ex officio, but only upon request of the defendant. If the court arrives at the conclusion the issue can be solved on the basis of the documentary evidence collected till that moment, after taking the opinion of the prosecutor, it decides to go with the abbreviated trial (Constitutional Court, 2012). And before making a decision the court must be acquainted with all acts or evidence gathered during the investigative phase, by taking into consideration also those acts remained in the prosecutor's file and not included in the trial file (Ligori, 2004).

The judge takes the decision based on his inner conviction (Constitutional Court, 2014) and the prosecutor consensus is not obligatory, since he has the right to appeal the court decision for accepting the defendant request for abbrevviated trial, together with the final decision. In each case the prosecutor has the legal obligation to argue before the court on the reasons why the defendant request should not be accepted (Supreme Court Criminal College, 2011) (Corte Constituzionale, 1998).

If the court proceeds with abbreviated trial the prosecutor's file becames the court's file and no more evidence, except those collected in the preliminary investigation phase, can be taken in the hearing (Cass. Pen. Sez IV, 2012) (Supreme Court United College, 2003). At this stage of the proceeding the court cannot evaluate the probative force of acts during the preliminary investigation phase. The court may reject the request, if considers that a judicial debate is necessary and in this case the trial continues with the usual procedure, respecting the principles of due process of law (Constitutional Court, 2013).

The interest to proceed with the abbreviated trial, is mutual for both parties, but the parties' benefits and interests should not go at the expense of doing justice.The defendant's benefits are: firstly, in the case of a guilty verdict, the defendant receives a reduced sentence in its third and, the court cannot give punishment to life imprisonment, which will be replaced with 35 years imprisonment. Secondly, the defendant considers that based on the status of documentary evidence and acts in the file the court cannot sentence a guilty verdict (Ligori, 2004). On the other hand the prosecution benefits are: firstly, this type of judgment simplifies and shortens the procedure, increases the speed and the efficiency of the trial (Supreme Court United College, 2003). Secondly, it helps to encrease efficiency in the implementation of the criminal law, to punish the offenders, because in a inquisitorial system is easier to prove the defendant's guilt (Ligori, 2004).

\subsection{Invalidity of procedural acts and non-utility of evidence}

In Unifying decision no. 2, dated 29 January 2003, inter alia, the United College of the Supreme Court said that: "If the court accepts the request for an abbreviated trial, the parties may not submit claims regarding the invalidity of acts, whether absolute or relative invalidity... Otherwise, the court shall revoke the decision for an abbreviated trial and order the continuation of proceedings with ordinary trial ... ".

Otherwise than above, I think that, even during the abbreviated trial the parties shall be entitled to require a finding or declaration of nullity of acts, and to raise claims for non-utility of evidence. In the case of an abbreviated trial, the defendant with his free will waives from some of the rights offered by domestic legislation such as: the right to a public hearing (Kwiatkowska v. Italy, 2000), the right of discussion and the possibility to request the presentation of new evidence and call his witnesses, guarantees which constitute fundamental aspects of the right to a fair hearing enshrined in Article 6 of the Convention (Sccopola v. Italy, 2012).

The rights enshrined in Article 6 of ECHR are not absolute and there is room for implied limitations. These limitations should not curtail the rights in question to such an extent as to impair their very essence and deprive them of their effectiveness. It is against the principles of legal certainty, foreseeability and equality before the law that the State 
can, unilaterally, reduce the advantages arising from the notion of due process. Contracting States are not bound by the Convention to foresee in their legislation the posibility for simplified procedures, but however these procedures exist the defendant should not arbitrarily be deprived of the advantages associated with that procedure.

So, the defendat or his counsel may submit claims regarding the invalidity of acts, whether absolute or relative invalidity, and the non-utility of evidence. The denial of such a right constitutes a violation of Article 6 of the Convention, the right to a due process, which applies to any judicial procedure including special trials. The defendant agrees to be tried in the state that the acts of prosecutor's file are, as long as the evidence is providet in accordance with the requirements prescribed by the provisions of the CCP. A trial conducted on the basis of illegal acts, constitutes a denial of justice (Cass, pen., 2000). The Court should in each case decide based on acts and evidence legally drafted and collected (Tonini, 2010).

\subsection{Changing the legal qualification of the offense during the abbreviated trial}

The notification of the charges to the defendant is very important in criminal proccedings and he should be informed in due time of the factual basis, the cause of the accusation (the acts he is alleged to have committed and on which the accusation is based), and legal basis of it. A full, detailed information concerning the charges against a defendant, and the legal characterisation are essential for a fair hearing as guaranteed by Article 6.1 of the Convention, especially the accused's right to prepare his defence (Pelissier and Sassi v. France, 1999).

In case the court decides to accept the request for abbreviated trial and proceeds with that, changing the legal qualification of the offense puts the defendant in unfavorable positions towards the prosecution (Corte Constituzionale, 2010). When submitting a request for an abbreviated trial the defendant accepts the charges as they are formulated by the prosecutor, and in the case of changing the offenses or adding aggravating circumstances, he would be found in the inability to realize his defence or to request the admission of evidence that would absolve him (Corte Constituzionale, 1994) (Corte Constituzionale, 2009).

The right of changing the legal qualification of the offense should be exercised in accordance with the particulars of the abbreviated trial. To proceed with this kind of trial, the approval decision of a judge is required. The judge in making such a decision should be guided not only by the principle of judicial economy, but primarily by the principle of effective justice. Among others should take into consideration the legal qualification of the offense specified by the prosecutor and in case of any doubt the judge should decide not to accept the request and to continue the normal procedure, thus respecting all principles of due process as the right for a public hearing, the right of defense, equality of arms etc (Constitutional Court, 2002) (Cass. Pen. Sez.II, 2012).

When the court proceeds with the abbreviated trial, based on the acts of preliminary investigation, without debating about the their probative value, the defendant position becomes weak compared that in ordinary judgment. It these cases, the process gains in terms of efficiency and costs, but the possibility of judicial error is higher and is easier to prove the guilt of the accused. As the Constitutional Court notes in its decision, changing in peius the legal qualification of the offense, could aggravate the consequences related with the infringement of the right to defense.

\section{Conclusions}

1. During the preliminary phase of the trial the judge, in order to prepare the case for trial, performs several preparatory actions, but without seeking to ensure an effective process within a reasonable time. The pre-trial stage, as it is today according to the Albanian CCP, does not really prepares the parties for an equal and fair process.

2. The prosecutor remains the dominus of the preliminary investigation phase and the criminal charges formulated by him are not subject to judicial control. This regulation is inspired by the systems which have used the inquisitorial model and violates the accused rights. The content of the judicial file is of a fundamental importance and the current system does not give the defense effective opportunity to balance the interest, since the formation of the trial file is made by the prosecutor and the defense has no role in the process. The defence right to submit memos is insufficient.

3. During the pre-trial phase the defendant has the right to request for abbreviated trial. If the court decides that the case can be resolved on the basis of the documentary evidence, as they are in the prosecutor's file, it proceeds. In making such a decision the judge should be guided not only by the principle of judicial economy, but primarily, should gurantee an effective process. The defendant has the right to claim the absolute nullity of the acts and the non-utility of the evidence obtained unlegally. 
4. If the court proceeds with abbreviated trial, which aims to resolve the matter on the basis of preliminary investigation acts, without debating on their probative value, the defendant's position becomes weaker as compared to that in ordinary judgment. Therefore, the court should not change in peius the legal qualification of the offense.

5. Incompleteness of the investigation and the refusal of the defense request for evidence in the preliminary investigation stage, denies to the defendant the possibility to proceed with abbreviated trial. A pre-trial judge, entitled with the competence to integrate the prosecution evidence with those presented or requested by the defense, would solve this problem.

\section{References}

Case Andreucci v. Italy. (1992). Application no. 12955/87, pg. 17. (Online) Available: http://hudoc.echr.coe.int/eng\#\{\%22fulltext\%22: (\%22Andreucci\%22),\%22languageisocode\%22:(\%22ENG\%22),\%22documentcollectionid2\%22:(\%22GRANDCHAMBER\%22,\%2 2CHAMBER\%22),\%22itemid\%22:(\%22001-57723\%22)\} (September 01, 2016).

Case of Angelucci v. Italy. (1991). Application no. 12666/87. pg. 15. (Online) Available: http://hudoc.echr.coe.int/eng\#\{\%22fulltext\% 22:(\%22Angelucci\%22),\%22languageisocode\%22:(\%22ENG\%22),\%22documentcollectionid2\%22:(\%22GRANDCHAMBER\%22, \%22CHAMBER\%22),\%22itemid\%22:(\%22001-57664\%22)\} (September 01, 2016).

Case of Buchholz v. Germany. (1991). Application no. 7759/77. pg. 49, (Online) Available http://hudoc.echr.coe.int/eng\#\{\%22itemid \%22:(\%22001-57451\%22)\} (Septemebr 03, 2016).

Case of Eckle v. Germany. (1983). Application no. 8130/78. (Online) Available: http://hudoc.echr.coe.int/eng\#\{\%22itemid\%22:(\%2200157475\%22)\} (September 03, 2016).

Case of Guincho v. Portugal. (1984). Application no. 8990/80. pg. 35-41 (Online) Available: http://hudoc.echr.coe.int/eng\#\{\%22itemid \%22:(\%22001-57497\%22)\} (September 02, 2016).

Case of H. v. France. (1989). Application no. 10073/82. pg. $48-59$ (Online) Available: http://hudoc.echr.coe.int/eng\#\{\%22itemid \%22:(\%22001-57502\%22)\} (September 02, 2016).

Case of Kwiatkowska v. Italy, Application N0. 52868/99, date 30 November 2000.

Case of Kutic v. Croatia. (2002). Application no. 48778/99. (Online) Available: http://hudoc.echr.coe.int/eng\#\$2\%22documentcollectionid2 \%22:(\%22GRANDCHAMBER\%22,\%22CHAMBER\%22)\} (September 01, 2016).

Case of Pelissier and Sassi v. France. (1999). Application no. 25444/94.pg.51-54. (Online) Available:http://hudoc.echr.coe.int/eng \#\{\%22itemid\%22:(\%22001-58226\%22)\} (September 02, 2016).

Case of Scopellitti v. Italy. (1993). Application no. 15511/89. (Online) Available: http://hudoc.echr.coe.int/eng\#\{\%22itemid\%22:(\%2200157859\%22)\} (September 02, 2016).

Case of Scoppola v. Italy. (2012). Application no. 126/05. (Online) Available: http://hudoc.echr.coe.int/eng\#\{\%22fulltext\%22:(\%22 scoppola\%22),\%22languageisocode\%22:(\%22ENG\%22),\%22documentcollectionid2\%22:(\%22GRANDCHAMBER\%22,\%22CHA MBER\%22),\%22itemid\%22:(\%22001-111044\%22)\} (September 04, 2016).

Case of Vocaturo v. Italy. (1991). (Online) Available: http://hudoc.echr.coe.int/eng\#\{\%22itemid\%22:(\%22001-57717\%22)\} (September 04, 2016).

Case of Zimmerman and Steiner v. Switzerland. (1983). Application no. 8737/79. pg. 29, (Online) Available http://hudoc.echr.coe. int/eng\#\{\%22fulltext\%22:(\%22Zimmermann\%20and\%20Steiner\%22),\%22documentcollectionid2\%22:(\%22GRANDCHAMBER\% 22,\%22CHAMBER\%22),\%22itemid\%22:(\%22001-57609\%22)\} (September 05, 2016).

Cass. pen., 2000, 3259 e in Guida dir. , 2000, 31 , 73, nota di R. BRICCHETTI, La richiesta di accesso al rito semplificato non è una rinuncia ad eccepire gli atti viziati, ivi, 81 .

Cass., sez. Un. (2005). n. 12283, Pg. In proc. De Rosa, in Dir. Giust., 2005, 17, 36.

Cass., sez. un., 20 dicembre 2007, Battistella, in Guida dir. , 2008, 11 , 60, con notta di S. Lo Russo.

Cass., sez. un. (20 dicembre 2007 - $1^{\circ}$ febbraio 2008). n. 5307, Battistella, in Dir. pen. proc., $2009,177$.

Cass., sez. IV. (2007). T.D., in Riv. it. dir. proc. pen., 2008, 365.

Cass., pen., Sez. IV, 20 Novembre 2012 - dep. 12 Febbraio 2013, n. 6969, Carani, Rv. 254478.

Cass., pen., Sez. II, 18 dicembre 2012 - dep. 9 gennaio 2013, n. 859, Chiapolino, Rv. 254186.

Codice di Procedura Penale Italiana.

Constitutional Court. (2012). Decision no.4. (Online) Available: http://www.gjk.gov.al/web/Vendime_perfundimtare_100_1.php (September 05, 2016).

Constitutional Court. (2013). Decision no. 6. (Online) Available: http://www.gjk.gov.al/web/Vendime_perfundimtare_100_1.php (September 05, 2016).

Constitutional Court. (2014). Decision no. 16. (Online) Available: http://www.gjk.gov.al/web/Vendime_perfundimtare_100_1.php (September 05, 2016).

Corte Constituzionale (1994). n. 264

Corte Constituzionale (1998). n. 33.

Corte Constituzionale. (2001). n. 224.

Corte Costituzionale. (2002). n . 333, 
Corte Constituzionale (2009). n. 140.

Corte Constituzionale (2010). n. 140.

Lattanzi. G. (1994). II sistema processuale penale italiano: profili strutturali e funzioni generali, In Atti del corso di formazione per magistrati albanesi. (Volume II, pg. 315). Roma.

Ligori, H. (2004). Disa mendime për gjykimin e shkurtuar. Revista Tribuna Juririke (No. 48), Tiranë.

Picardi, L. (2014) L'udienza Preliminare: il suo svolgimento, i poteri integrativi del giudice e gli standard probatori per il rinvio a giudizio (pg. 36). (Online) Available: http://volontaria.altervista.org/LEGGE\%20CERIELLI/UDIENZA\%20PRELIMINARE.pdf (September 05,2016 ).

Siracusano, et.al. (1996). Diritto procesuale Penale (pg. 196-203, 714). (Volume secondo, Seconda edizione). Milano: Giuffre Editore.

Supreme Court Criminal College. (26 January 2011). Decision No. 16. (Online) Available: http://www.gjykataelarte.gov.al/web/ Kerkim_per_Vendime_37_1.php (September 05, 2016).

Supreme Court United College. (29 January 2003). Unifying Decision No. 2. (Online) Available: http://www.gjykataelarte.gov.al/web/ Vendime_Unifikuese_39_1.php (September 05, 2016).

Tonini, P. (2010). Manuale di Procedura Penale (pg. 566-570). (XI edizione). Milano: Giuffre Editore. 
ISSN 2039-2117 (online)

ISSN 2039-9340 (print)
Mediterranean Journal of Social Sciences MCSER Publishing, Rome-Italy
Vol 7 No 6 November 2016 